\title{
The Convention of Geneva, and the Care of Sick and Wounded in War
}

\author{
Mr. John Furley
}

To cite this article: Mr. John Furley (1896) The Convention of Geneva, and the Care of Sick and Wounded in War, Royal United Services Institution. Journal, 40:224, 1215-1234, DOI: $10.1080 / 03071849609416276$

To link to this article: http://dx.doi.org/10.1080/03071849609416276

册 Published online: 11 Sep 2009.

Submit your article to this journal $₫$

Џ Article views: 3

Q View related articles 5 


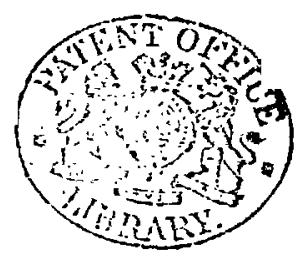

\section{THE CONVENTION OF GENEVA, AND THE CARE OF SICK AND WOUNDED IN WAR. B., TH. JOHN FCRLEI:}

Friday, 24th April, 1896.

The Right Hon. Viscocisr Kxutsiokd, G.C.MI.G., in the Chair.

Lord KNETSFoRD : It is my first duty to introduce to you Mr. Furley, who is good enough to give us an address this afternoon. I slould just like to say that one cannot very well attach too much weight to what Mr. Furley says upon this occasion, because I do not think there is anyone in this country, indeed I may say in any other country, more competent to give an opinion upon the questions that are raised by his address than Mr. Furley. He has spent much of his time, and has been at much trouble and considerable expense, in working out and establishing the best modes for relief for sick and wounded; and he has not donc this while sitting quictly at his ease in an armchair in London, on the contrary, he has had great practical knowledge of the work that is done and he has seen it on the field of battle. I need hardly remind those who know Mr. Furley of his work, but some may not know that work, and to them I would point out that Mr. Furley wats director of ambulances during the Franco-German War of 1870, that he was direclor of the flying ambulance attached to Marshal Mac. Mahon's army when they were fighting the Commune in 1871 , that he was also in the Carlist war, and $I$ believe in Montenegro in 187T. Therefore, Mr. Furley has had a practical knowledge of the working of the Convention of Geneva, and also of ambulance work. With these few observations I beg to ask Mr. Furley to be hind enough to address us.

\section{LECTURE.}

THE Convention of Geneva was drawn up in 1864; within six months it was signed on belualf of eight European States, including Great Britain, and at the present time it has been accepted by thirty -six Gorernments.

A red cross on a white ground was adopted as the badge of neutrality, and since 1864 thirty-seven national Red Cross Societies have been formed, each with an independent national existence, but with one international object, namely, the amelioration of the position of sick and wounded soldiers in war.

It is popularly supposed that the purpose of the convention was to establish Red Cross Societies; this is an error; the treaty makes no mention of such societies; but it is true that by taking voluntary aid to the victims of war under its protection, it suggested the formation of Red Cross Societies. 
After an experience of thirty-two years, it might be imagined that there was nothing new to be said on this subject, and that, especially in every country possessing a Red Cross Society; the meaning of the badge would be thoroughly understood; but this is far from bcing the case. On the Continent of Euroje, where national jealousy, fostered by commercial rivalry and stimulated and encouraged by continuous and ostentatious preparations for war, is always on the alert, it is perhaps natural that the effects of past wars should not be forgotten or ignored; but it is quite otherwise in our island home. We trust to the Gorernment of the day to keep the country prepared for war; but we have no conscription to affect every: family and business establishment, and military preparations are on a smaller scale and less conspicuous. Centuries have elapsed since our shores were invaded, and from the time of the Crimean war, although we have never been free from little wars and expeditions in remote parts of the world, not one has occurred to strain to the utmost the moral and physical resources of the nation, or to bring it into immediate touch with the complicated horrors of invasion.

Twenty-six years ago, a great war between neighbouring Powers roused England from its apathy, and the deepest sympathies of all classes of the community were manifested by the efforts made to do something towards the alleviation of the sufferings of those who were being mown down by thousands on the field of battle, as well as for the benefit of the countless victims represented by the widlows and orphans and the owners of devastated fields. Then it was realised how, notwithstanding national prejudices kept alive by irresponsible writers and selfish speculators, civilisation has succeeded in forging links between nations, which, though powerless at present to make war an impossibility, are sufficient to compel those engaged in it to look upon the wounded foe as no longer an cnemy, and to treat the victims of war as worthy of the greatest consideration and compassion. Every country in the civilised world joined in this great mission of mercy, and never before was the brotherhood of nations so apparently at the point of realisation: but more than a quarter of a century has passed away, and we now seem as far as ever from this desired consummation. Wars have not ceased, nor is it likely they will do so, judging from the annually increasing growth of armies, the expenditure on behalf of fleets, and the general uneasiness which prevails.

I have thus only lightly touched on questions which are being daily treated by speakers and writers whose qualifications are far beyond those to which I make any pretension; but as one who has had a considerable cxperience of the terrible and wide-spreading effects of war, and who recognises that these are more equally divided than is generally supposed between the vanquished and the victors, I am anxious to bring before civilians one of the responsibilities incumbent on them, and thus, perhaps indirectly, to infuence the military authorities by convincing them that it is a subject in which they are immediately concerned. A civilian's participation in the defence of his country does not cease with his pecuniary contribution towards the Army and Navy; there is something more than this required of him. 
It is not a popular thing to suggest that a forcign foe may some day effect a landing on our shores; nerertheless, this is a subject which military men have to consiler as a serious possibility; it is, therefore, no less incumbent on the civilian to be prepared for such an eventuality. Any amount of care and forethought shown in this direction will do nothing to encourage war, but should an invasion take place, it would uncloubtedly lessen many of the attendant horrors, whether the enemy succeeded in advancing or were driven back from our shores.

This paper must, however, be confined to one phase only of war, namely, the means at our disposal for the care of the sick and wounded in war. Great as is the ignorance which prevails, no one with any knowledge of this matter would, I think, be found to assert that these means could be entirely provicled by the Navy_and Army Medical Departments. For these two eminent branches of our military services $I$ have the very greatest respect, founded on a personal knowledge of many years, and an experience which enables me to assert that, although their members may be classed among the non-combatants, they have never been found to shelter themselves under this appellation when a deed of mercy or courage has called for a display of the grandest military qualities. Does not the roll of the Victoria Cross prove this by the percentage it shows of medical officers?

It is only natural that military authorities should bestow more attention on all the means which may contribute to the gaining of victories over their enemies, rather than engage in the uncongenial task of worrying a Chancellor of the Exchequer by proposing additions to the Estimates under the head of field-hospitals. It is one of the difficulties created by our insular position that we cannot regard the prospect of war in the same comprehensive manner as our Continental neighbours, and, therefore, it is that on this one important subject, the treatment of the sick and wounded in war, we are slow in following the examples we have before us in the great armies of Europe.

I would that I had the pen of the able writer of "The Battle of Dorking"; not that I might describe the confusion which would be caused by a hostile landing and a march on London; but rather that I might indicate the absence of confusion in everything concerning the sick and wounded, which would be the result of previous preparation and a strict adherence to the Convention of Geneva.

This treaty is one of the most remarkable facts of modern times; it is bricf and simple, and it should be an obligatory subject in the instruction of every man who serves in the Army. I would go a step further, and say that it would prove a far more useful item of instruction than many of those included in the programme of our Board Schools, and not the less so that its meaning could be made quite intelligible in the course of a single hour.

It cannot be too generally known that when a country is in the occupation of a foreign foe, a knowledge of the Convention of Genera is quite as important to the native civilians as it is to soldiers of the invading army. Since 1864 , as I have already remarked, many Red Cross Societies have been formed, and, as may well be imagined, they 
have passed through many vicissitudes. In 1870, when the FrancoGerman War broke out, a very confused idlea prevailed as to the meaning of the Red Cross badge, and many mistakes were made; nevertheless, so much good resulted from its use as a neutral sign for the protection of sick and wounded soldiers; and also of those who had charge of them and the buildings in which:they were lodged, that no proposal has ever been seriously made for the abrogation of the Genera Treaty. That thebadge was undoubtedly abused cannot be denied, but this only proved the necessity of making a knowledge of the powers conferred by the treaty universally known, and also placing some restriction. on the assumed rights of " benevolent neutrals."

In those days the general impression seemed to be, that any man or woman wearing a white armlet with a red cross upon it was free to go pretty much where he or she thought fit, with a proud contempt of such things as military passes. A large proportion of these armlets were homemade, and had not even the official stamp of any military authority in either of the belligerent armies. Then, again, Red Cross flags of various forms and sizes were hung over innumerable houses, whether the roofs sheltered wounded men or not. This matter was rectified by an order that no such flag would be recognised unless there were a certain number of beds in the house actually occupied by invalids.

No badge has ever been more generally abused, both in peace and war, than the Red Cross, and unfortunately it has not been made a penal offence to use this distinctive emblem without legal authority, although in time of war any persons so wearing it would soon find themselves in a very unpleasant position. 'This ignorance has led to the use of the Red Cross badge as the recognised mark of a hospital or even the house of a private nurse, and various socicties have adopted it, to say nothing of vendors of patent foods and medicines.

It cannot be too strongly insisted that the Red Cross is a military and not a civil badge, and, from a military point of view, no person is authorised to use it without official authority. The Army Medical Corps is, or ought to be, in exactly the same position in this respect as a civil ambularice corps. On the outbreak of a war in which we might be engaged with other Powers, signatories of the Convention of Genera, either as allies or adversaries, every officer and man engaged in hospital work would have served out to him a white armlet with a red cross, authenticated with the proper official stamp. 'These armlets form part of the uniform on active service, and have to be returned into store at the end of a campaign.

The little Red Cross badge worn on the right arm of the non-commissioned officers and men of the Army Hospital Corps has no more significance outside the British Army than any other regimental badge. I venture to think it was an unfortunate mistake when this badge was aclopted.

We have a good example of the fact that the little red cross as now worn by the non-commissioned officers and men of the Army Hospital Service is only a corps badge, and not an 
equivalent to the Red Cross armlet with an official stamp: and it makes little difference to $\mathrm{my}$ contention that $\mathrm{I}$ cite a case which occurred when, the Convention of Geneva not having been adopted by both belligerents, the Red Cross could not be acknowledged as a badge of neutrality. On the- recent march of British troops to Kumassi, each man in the bearer-companies of the Army Medical Corps carried a rifle and seventy-five rounds of ammunition. Although we were then opposed to savages, it was unfortunate that the Red Cross should have been displayed in any form.

I may also refer to another case where ignorance on the subject was also shown. Some of the members of the St. John Ambulance Association recently went from the Cape to Krugersdorp, their services having been accepted by the Boers. A complaint has since been made that an armed Boer had a red cross on his arm. As the Transvaal Government had not adopted the Convention of Geneva, and neither side had received official sanction to wear the badge, any irregularity in regrard to its use was possible, and there could be no legitimate ground for complaining that the Convention had been violated on one side or the other.

I mention these two facts in order to strengthen my argument that the Convention of Gencra ought to be more widely known, especially in those countries where, as in our own, it has been adopted by the Government.

Great Britain having accepted and signed the Consention of Genera cannot ignore these details.

To be of any protection as a neutral badge, it is absolutely essential that the Red 'Cross should be equally respected by soldiers as well as civilians. For this reason, that part of an army which the Convention of Geneva was designed to make neutral should, under all circumstances, strictly observe the conditions imposed on it by this treaty. For instance, wagons used for carrying ammunition and other warlike stores to the front during a battle will not be treated as neutral, if also employed in taking wounded men to the rear, even though each vehicle may bear a Red Cross flag. The more distinctive in appearance the transport vehicles of a hospital corps can be made, whether military or civilian, the better. It must not be thought, however, that in these days of long-range firing, the field hospital or the hospital transport can be entirely exempt from stray shots. Fiven a ficld hospital may be found in the thick of a fight. All that can be done is to select such places for dressing stations and ficld hospitals as may seem to be fairly secure, and in no case must troops be allowed to use a hospital as a mask for offensive operations.

I need not remind you that I am not a military man, and I am only referring to inatters which have come within my personal experience.

Probably one of the most recent examples of attempting to improvise a Red Cross Society, and to place it in the field during a campaign, in which only one of the belligerents had accepted and acted on the Convention of Geneva, was afiorded during the recent war between China and Japan. 
With regard to this episode, I am allowed to give as my authority an interesting letter written by Surgéon-General Taylor, A.M.S., who was attached to the Headquarters of Marshal Oyama, Commander of the Imperial Japanese Army.

On the 30th November, 1894, "a Chinese steamer, the "Toonan," was captured by the Japanese Fleet just inside Port Arthur. She was found to have on board nine gentlemen respectively belonging to three nationalities, namely, Great Britain, the United States of America, and Denmark. On being asked what they wanted at Port Arthur, they presented a letter for the Officer Commanding the Japanese Army; stating that they represented the Tientsin Independent Red Cross Society, and had been sent out to give aid to the Chinese wounded.

The following is the verbatim reply of Marshal Oyana:-

"Gentlemen, I appreciate the humane object of your voyage to carry wounded soldiers to Tientsin to be taken care of by your society. At the same time, I beg leave to call your attention to the plain fact that the wounded enemy's soldiers, however humancly they be treated by the army in whose hands they are, are, after all, prisoners of war, so that the carrying of them from a land occupied by one of the belligerents cannot be called a neutral act. For this reason I am sorry to have to reject your offer. I.et this denial, however, be joined with the assurance that it is the rule of our army to take care of the wounded soldiers, without distinction of enemy or not enemy, so that the wounded Chinese soldiers are being actually taken care of in our field hospitals, and $I$ ask the gentlemen to have no anxiety about the matter.

"Please to understand that communication has been male to the commander of our flect that the steamer "Toonan," on which 'you now are, shall be made to leave the waters about Risjan Peninsula before 6 p.m., 30th November. (Signed). Orasi,

"Commander of the Imperial Japanese Army."

I venture to think that this letter leaves nothing to be desired either in form or spirit, and it is an excellent illustration of the manner in which the Convention of Geneva has been adopted and is understood in Japan.

Such a benevolent expedition as the one just mentioned might, perhaps, have succeeded in passing in 1870 , but "independent " neutrals will not in future be allowed to float the Red Cross flag in this manner, more especially if they do not possess official sanction from either of the belligerents and can only plead the best intentions.

The fact that this expedition was made in Chinese waters, to a port that had just been captured by the Japanese, suggests an allusion to the great difficulty that has hitherto prevented Red Cross arrangements, possible in armies, from being extended to naval warfare. A hospital ship flying the Red Cross, and anchored at a point where it could not interfere with the enemy's movements either on sea or land, would doubtless be treated as neutral by the naval and military forces of any State that had accepted the Convention of Geneva. One of the insuperable objections is, that such a vessel could not be allowed to enter a port belonging to 
either of the belligerents for the purpose of landing or embarking invalids of the fleet, if the enemy were able to prevent it.

I have mentioned the Franco-German War as the first campaign in which the effect of the Convention of Geneva was experienced on a large scale. The way in which each of the National Red Cross Societies then worked reminded one of the manner in which our Volunteer Army was gradually. developed: Wach corps acted very much on rules of its own, which ivere gradually modified to suit the requirements of the military chiefs under whom it happened to be working. Some were amenable to discipline, others were not; but as all had the same object, and the field was a very big one, considerable latitude was allowed.

Since that period the military Powers, especially France, Germany; Italy, and Russia have done much to organise the Volunteer Red Cross Societies, and to bring them into harmony with their respective armies. In no future war will such freedom be allowed as was witnessed in 1870-71, and it is eren doubtful if the services of neutrals from States, other than belligerents, will be allowed to intervene; or, if permitted to do so, they will have to serve under the orders of the chief of that army to which they may be attached.

About thirty-seven National Red Cross Societies have been formed since 1864. I would here draw attention to the rule laid down by the International Committee at Geneva that only one Red Cross Society is recognised for each country; colonies included, as any departure from this regulation would lead to serious complications:

Time will not permit me to describe the manner in which each of these central societies has been developed; a detailed account of the organisation and work performed by them all would fill many volumes. Soon after the first establishment of these Societics, it was admitted that, to keep the work up to the level of the requirements of war, it would be necessary to practise and prepare in time of peace; most of the Societies have, therefore, undertaken to train men and women for that large field of usefulness which is to be found in the accidents, epidemics, and disasters of all kinds in civil life.

It is unnecessary for me to describe here the very great part taken in 1870-71 by the British National Aid Society (which is our National Red Cross Society), and also the assistance it has afforded on other occasions when the British Arny has been engaged. - Nor is it necessary to describe what the St. John Ambulance Association has done. Combine the objects of these two institutions, and you have what the great military States of Furope are striving to obtain-an inexhaustible supply of men and women daily engaged in the alleviation of pain and suffering, from which at short notice, a well-trained, useful, and intelligent supplement can be formed for the Army Hospital service.

I hope I shall not be accused of undue self-assertion if I mention the success which has attended one step that has been taken in England towards realising this desire to train and organise a body of men and women who could be relied on, in case of necessity, to act as a reserve to the Army 
Hospital Corps, and who, meanwhilc, are daily employed in ministering to the relief of the sick and wounded in time of peace. I refer to the St. John Ambulance Brigade, of which I formed the nucleus when I had the honour to be Director of the Ambulance Department of the Order of St. John, and which is surely, if slowly, developing into a very useful body. We had at hañd a large number of men who had been instructed in First-Aid; but something more was required, even for peace time, to give cohesion and stability to this excellent personnel. Several corps were therefore formed in different parts of Fngland; and I have no hesitation in saying that this organisation can be readily extended, especially if faroured by official support. Some of these corps have been inspected by the present Director-General of the Army Medical Department and other officers appointed by him, and their reports are in the highest degree satisfactory and encouraging. I may also mention the review of the Tibshelf and Birchwood Colliery Ambulance Corps by Her Majesty the Queen at Windsor, a gracious act which will never fatle from the memory of those who were privileged to take part in it.

If, as yet, I have said little with regard to female nurses, it is because they form a subject which comes rather within the province of others who are more competent than myself to speak on it, and because their training for peace, as well as for war, must be more complete and extensive than in the case of the majority of the men to whom I have just referred. First-aid nurses who have been instructed and enrolled by the St. John Ambulance Association are doing admirable service, especially in some of the colliery districts, as many surgeons will-testify, but for real hospital work only a long course of training and experience, extending over two or three years, is sufficient to bring them up to a safe and proper standard of efficiency.

In the direction thus indicated I am, perhaps, an enthusiast, some may call me a fanatic; but for this object-the organisation of civilians in time of peace as a strong ambulance supplement for time of war--I have striven for nearly thirty years, and I never felt more sanguine of its realisation than I do to-day. I should like to mention the names of colleagues and friends of different nationalities with whom I have been associated, and from whom $I$ have received the best advice and the greatest encouragement; but I fear I might omit some by inadvertence and compromise others by my zeal. One, however, I may recall without hesitation, whose loss we are still mourning, and who was regarded with affectionate esteem by his friends and associates in this country and throughout the civilised world, for his amiable qualities, professional ability, and exhaustive knowledge in all that pertains to military hospitals and ambulances and the Convention of Geneva, of which he was one of the mithors. The, name of longmore is written large on every page which treats of these subjects from the time of the Crimean War to the present date; and this name, modest and unassuming as was the man who bore it, will always be held in respect and admination wherever the victims of war are deemed worthy of the highest efforts of humanity. 
It would serve little purpose to occupy more time in describing what has been done in the past, unless it can be șhown how this country can make use of and improve on the experience which has been acquired. kach National Red Cross Socicty has been organised and developed on lines best adapted to its own conditions and circumstances. For reasons already slightly sketched, the Red.Cross idea has not made the progress in this country observable elsewhere. I do not propose to mention in detail all that these different societies have accomplished in peace and war, but will limit myself to the statement that Austria-Hungary, France, Germany, Italy, and Russia offer cxamples of certain portions of Red Cross work which might be followed with advantage in this country. But it is in France will be found the model best suited to the actual position of affairs at which we have arrived in regard to First-aid instruction, trained nurses, and civil ambulance material. In the organisation of these means for war purposes, we are at present far behind all the States just mentioned; but, if only we can arrive at a proper understanding, we shall be soon found ahead of them all, in everything needed as a Supplemental Rescrve to the Army Medical Service. It must not, however, be thought that this bold assertion refers to quantity and not to quality, but it means that out of the superabundant quantity now existing, a sufficient nucleus of most excellent quality can be obtained.

'The French Red Cross Society', established in 1864, was founded on lines very different to those which it now follows, and its whole system was completely modified by the sad experiences of 1870-71. Nor has it been wholly independent of political influences and changes of Government. Be this as it may, the outcome, considered as a model of good organisation, is most satisfactory:

This society is now divided into three separate bodies, each keeping its own name and having its own rules in time of peace, but all of them controlled by the Minister of War. La Socielé de Sicours aux blessés des Armes de terre el de mer, the original French. Red Cross Society, was established in 1864. In 1884, a decree was passed with the object of bringing the society into harmony with the military changes that had taken place since the war of $1870-\tau 1$, and authorising it to supplement in time of war the military sanitary service, to distribute gifts offered by public generosity, to establish hospitals in places that may be indicated as requiring them, to render assistance in the transport of sick and wounded soldiers, in the railway station infirmaries (a creation of the FrancoGerman War), and in all the auxiliary hospitals at the seat of war. Since this decree of 1884, two others have been passed, dated respectively 16th November, 1886, and 21st December of the same year. The first recognises l'Association des dames franģaises, and the second, l'Union des femmes de France. These decrees limit the co-operation of the abovenamed aid-societies with the military medical service to the rear of active hostilities and to the national territory.

Irrespective of this assistance, the three societies are authorised to distribute to the sick and wounded any gifts they may collect. The relations of the three societies with each other and with the officin! 
directors of the medical service are defined by the above decrees. Every establishment of the aid-societies is under the surveillance of the principal medical officer of the district in which it is situated, who also superintends all the documents and registers prescribéd.

The personnel of the three socicties is authorised to wear a uniform and the badges approved by the Minister of War. All associations in France, which more or less pursue the same object and which cannot be recognised as independent societies, are required in time of war to become merged in the Siciélé de Secours aux blessés des Amées de terre et de mer: 'Ihere is only one exception to this rule, and that is in favour of those strictly local ambulances whose action does not extend beyond the communes where they are established.

Already at many of the most important railway junctions on the principal lines between Paris and the frontier, not only have certain rooms been apportioned for the use of the Red Cross Society, but a large personnel and everything required for hospital use have been allotted for the same purpose. On the sutbreak of war each of these temporary hospitals could be placed on an active footing as rapidly as the mobilisation of the army can be effected; and besides, the delegates of the society: are charged with the useful duty of bringing back invalids from the front and accompanying the railway ambulance trains. 'These moveable and stationary hospitals form the special work of the Socielé de secours autx Ulessés mililaires in time of war, and they offer a lairge scope for the cxercise of national philanthropy without the danger and inconvenience to which reference has already been made.

Great attention is being paid by the French society (for I prefer to consider the three societies as one association) to the constant improvement of ambulance material: depots have been established in thirty-nine towns corresponding with thirty-nine territorial divisions of the army, and trials of this material are annually made at the period of the great mancurres. For the personnel, schools of instruction for ambulances and nurses have been formed in Paris, and also at Marseilles, Lille, and Nancy.

If I have dwelt at some length on the system adopted for making the Voluntary dicl Societies in France a reliable supplement to the Medical Department of the Army; it is because such an organisation seems to be the one best adapted to English needs. It cannot be too often repeated, that no official means for treating the sick and wounded can be adequate to the exigencies of a great campaign. The medical corps of every large army must have a volunteer reserve for great emergencies. If this were so in the past, and we know it was the case, how much greater will be the strain on the Army Medical Service in the future. Even during the last twenty-five years what a change has taken place! Henceforth wars will break out with little or no notice, and

1 The above brief description of the organisation of the French Red Cross Society is taken from the chapter on "The Convention of Geneva and its badge, the Red Cross," written by J. F., and published in the second edition of Longmore's "Manual of Ambulance Transport." 
though they may be of less duration than the campaigns and sieges of the past, the number of killed and wounded will be greater in proportion to the time. Improved small arms, long-range artillery, and quick-firing machine-guns will make it impossible to establish dressing stations in close proximity to the firing line, or to carry off the wouncled during the progress of a battle. So much the greater, then, will be the need of an increase in the hospital corps as well as in the means of ambulance transport. The whole available strength of the Army Hospital Corps will have to be as near the front as possible, and the care of the sick and wounded on the lines of communication and in the base hospitals must be left to others. If this reserve be not carefully and systematically organised in time of peace, it will be a cause of trouble and vexation to the authorities at the critical moment, the personnel will prove insufficient and undisciplined, gifts of stores will be doubtful in quality and superabundant in quantity, and the ordinary civil hospitals will suffer in proportion, by loss in their staff and by a wasteful expenditure of good material.

In 1892 I had the honour to read a paper in this Institution on "Ambulance Work and Material in Peace and War." On that occasion, I spoke of the improvements which had been made in stretchers, and added some suggestions which 1 considered, if carried out, might be to the advantage of those wounded in battle. MY friend, Mr. Archibald Forbes, criticised in a playful manner $m y$ interest in military stretchers, and qualified as a waste of time thoughts devoted to the subject of stretchers for the battle-fields of the future. The same able writer, in his very interesting solume entitled "Nemories and Studies of War and Peace," again returns to this subject. He has done this in a manner so friendly to myself personally, that I am encouraged to ask him and those who agree with him, to give the matter a little further consideration. 'The military stretcher must remain the most important of all means of transport for sick and wounded men. Admitting the state of things, so forcibly and graphically described by Mr. Forbes, that will exist in the future after a great battle, in consequence of the immense number of wounded, which the altered conditions of military armaments and new methods of fighting will concentrate in exposed parts of the field in an incredibly short space of time, is there any reason why we should refrain from all attempts to do* the uttermost in our power to remove the wounded to dressing stations and hospitals the moment that a cessation from the anticipated hail of projectiles may render such service possible? If the means of transporting the wounded from the field of a great battle are at present insufficient, that Government, which might neglect to make the Hospital Corps in some degree adequate to the requirements of its army, would, indeed, incur a most serious responsibility:

Mr. Forbes has quoted, in support of his views, the late Professor Billroth and Surgeon-General von Bardeleben; but I have read the published opinions of these two great surgeons in a manner quite different, and I personally knew them well enough, to feel assured that they would 
have neglected no means of clearing a battle-field of wounded men the very moment it might be possible to do so.

In 1892, at the International Conference of Red Cross Societies, held at Rome, a communication made by Sir.'Thomas I.ongmore was read in support of the views expressed by Professor Billroth, and this concluded as follows:- "Everything thus tends to show that while the number of sufferers urgently requiring help will be vastly increased in future wars, the means of affording them shelter and surgical attention will be pushed back to a greater distance than has ever before been necessary. If a battle is fought on a very large scale, the number of wounded men most pitifully demanding aid will be so vast that obviously the arrangements made to meet the wants of the probable number of wounded under former circumstances will be quite inadequate to meet future needs. The question then arises, whether the system of volunteer help to the wounded by neutrals, which was, in fact, accepted by both the French and Germans during the war of 18 $70-71$, and in principle is admitted under certain restrictions in the official regulations of most countries, should not be more largely developed, in order to meet the necessities of the wounded, in case, unhappily, hostilities on a large scale should again arise in Furope."

In a speech made by Surgeon-General von Coler to an assembly of delegates of the German Red Cross Societies, the distinguished head of the Prussian Army Medical Department made the following remarks :-“" It is now universally admitted that the great task imposed on the Sanitary Corps, on the outbreak of war, cannot be accomplished without the help of voluntary assistance. This aid should go hand-in-hand with the official services; they should be constituted on the same principle and based on one solid organisation; they should unite their efforts in order to be able to perform all their duties. It must not be forgotten that with the torrents of troops one country can now pour upon another in the space of a few days, armed with the present highly perfected and terribly destructive weapons, an immense task would be instantaneously set before the Sanitary Corps, and one with which it would be impossible for them to cope, unless everything were ready, beforehand for such a sudden and awful erentuality. Unity of direction in war, unity of direction -in peace, that is what we need. In the same way as the Army is sub-divided in fractions of varied importance subordinated one to the other, so voluntary aid ought to be hicrarchically divided, under one absolute control, whence should issue all orders and all decisions, which should also designate for each function to be fulfilled the most capable man, whose duty, cven in time of peace, should be to make himself familiar with the work which would devolve upon him in time of war.

Much has already been done in this clirection, in forming an instructed and exercised personuel; and yet the practical side, that is, the nursing of the sick, ought to be much further developed. 'The transport of the wounded from the hospital stations on the lines of communication, from the temporary hospitals to the railway trains; then, again, intelligent activity within the hospitals, more especially require education and 
prolonged and attentive instruction. Many hospitals have opened their doors and allowed such practical work and training, and the result has been a great public gain for time of peace, as good nurses often succeed in preventing an epidemic from becoming more deadly than a war.

On the other hand, in what relates to material, a department in which it is equally necessary to be prepared beforchand, as far as it is humanly possible, the efforts of Red Cross Socicties shruld be directed to the acquisition and perfecting of portable hospitals destined to supply the necds and unhealthiness of particular localities; and, as is the case with the personnel, these morable barracks can be of the greatest use even in peace time."

I have quoted Dr. von Coler at some length, because he is an authority whose words will carry as much weight here as in his own country.

Do we possess in England the means, personnel, and matéricl, out of which such an effective supplement to the Army Hospital Corps can be formed? 'This question may be unhesitatingly answered in the affirmative. - We jossess it in a degree that has never been attained in any other country, much as we can learn from other countries in regard to its organisation and extension to the requirements of war.

Leaving out the Voluntecr Medical Staff Corps, which has its own defined duties to perform, there are two institutions which I have already named. These are the St. John Ambulance Association and the British National Aid or Red Cross Society.

Besides these, there is another most valuable and indeed indispensable element to be found in the existing organisations of female nurses. We all know the valuable patronage and practical assistance given to the British National Aid Society by the Princess of Wales during the last Egyptian Campaign, and the great interest taken by Her Royal Highness in everything that concerns the selection, training, and gencral welfare of female nurses. We also know, from the evidence of official records, that it has long been the aim and desire of the Princess Christian to form a national reserve of highly-trained nurses for the Army-Hospitals; and in this Her Royal Highness has already in a great measure succeeded, through negotiations entered into with several of the large hospitals of the metropolis. Such a project, if fully carried out and sanctioned by the authorities, would provide a reserve of experienced nurses which would be available at short notice as an efficient auxiliary of the Army and Navy Medical Services.

It would be out of place on this occasion, and presumptuous on $\mathrm{my}$ part, to submit any scheme by which these three bodies, so distinct and independent in time of peace, conld be organised for the work that has been indicated for time of war; but I may claim that for twenty-five years I have adrocated such an amalgamation, and having carefully watched the working of Red Cross Societies in France, Germany, Italy, and Russia, I have satisfied myself that the combination is possible, practicable, and desirable. It need disturb no programme laid down for peace-time, but, on the contrarg; it would stimulate to further efforts, by proving that on 
the broad field of humanity we can labour both in peace and war; and that in preparing ourselves to meet the accidents and epidemics of civil life, we are, at the same time, forming a valuable reserve, both in personnel and materiel, to the official means which exist for alleviating the sufferings of our sick and wounded soldiers and sailors in time of pressing national need.

Briefly summed up, our aim should be:-

a. A more general appreciation of the Convention of Geneva, which was signed and adopted by this country more than a quarter of a century ago, then pigeon-holed at the Foreign Office, and which has since remained almost a dead letter.

$b$ The recognition of the Red Cross as a military badge of neutrality, the abuse of which in time of war incvitably entails certain serious penalties, and which, therefore, in time of peace should be carefully protected.

c. The organisation of a powerful Red Cross Society, to be: formed from the institutions already indicated, acting within their present limits in time of peace, but entirely under military control for all war purposes.

Captain Sir Alrred Jephsos, R.N. (Retired) : I hope some good will come of this important lecture, and $I$ think the importance of it consists in the fact that if it is to be productive of any good it must be acted on whilst we are in a state of peace, because if once war breaks out in which this country is involved to a large degrec it will be too late to do anything. I am quite satisfied of the correctness of what Mr. Furley has said as to the means in this country of organising a large society to aid the Army Hospital Corps in case of an outbreak of war. We have an inmense amount of material and personnel, but it requires organising and adapting to the Army and to be brought under strict military discipline. In future wars you will not be able to do as was done, I understand, in the war of 1870 , where newspaper correspondents gallantly mounted the Red Cross and pushed to the front to gain information, and where, I believe, even nurses were seen well up to the front instead of being where they ought to be, in the rear. I do not say they went there to fight-perhaps it was the natural interest and curiosity which is characteristic of the sex, but I am told that that was the case. Unfortunately, I think, the badge of the Red Cross has been hawked about the country to almost a pitiable degree, and instead of any penal clause being enacted to keep it sacred so as to command the respect of contending armies it is now the sign of patent pill makers, jelly makers, and such like people, and I am afraid it is too late to correct that great mistake. I should like to say, speaking officially as Secretary General of the Order of St. John of Jerusalem, that I a m quite sure if any practical method could be adopted as a result of this lecture to-day the St. John Ambulance Association would only be too glad to afford every possible assistance that it could. I hope the outcome of this meeting may be that some gentlemen who are interested in this great question will give their names in to Mr. Furley, who is one of the greatest authorities in the world on this subject, that they will study this question and formulate some scheme of organisation for this great association, which after it has been thrashed out might perhaps be submitted to the War Office, and, if it is thought necessary, to the Government, who I have no doubt will support it.

Major ANDrew Maccure, late Tth Middlesex (London Scottish) V.R.: I have great plersure, ny lord, as president of the Volunteer Ambulance School of Instruction (formerly Volunteer Ambulance Department), in supporting 
my old friend Mr. Furley in this most important matter. For the last twenty years we have been organising amongst the Reserves and Voluntecrs, and we have now nearly 10,060 men trained. The work is not only carried on in England, but also in Canada and China, at Hong-Kong by my friend Dr. Cantlie, and also out in Australia and New Zealand. It is all for the same object, to attend to the wounded in case of war. If there is some possible way in which we can combine and assist the Army Medical Department in this most inportant work, I am sure we shall all be ready to do so. I thank Mr. Furley for his very excellent paper.

Colonel J. S. Yoxic (Dep. Comm. Gen., Retired): Mr. Furley has added another valuable record to the already long roll of his distinguished services in the cause of humanity by reading this important paper to-day. At no time could it have been more appropriately launched before the public than now when the nation has been, by recent erents, stirred from end to end with the apprehension that the time may come, and may be brought about any moment by unforeseen circumstances, in which the necessity will arise of putting our means of defence into thorough order and efficiency. But, although. I know my friend Mr. Furley very well, having had the honour to claim him as a comrade at the very interesting period of the Franco-German War, when we were both together at the German Army Headquarters in Versailles, and knowing Mr. Furley has been conversant with all that appertains to the interests of the sick and wounded in war, I hope he will forgive me for saying that he fairly takes away my breath when he propounds such a large scheme as he sets forth in his paper. Happy as I should be to work with him in the same spirit that we have always worked together, I cannot help feeling that, perhaps as a civilian and one untrammelled by cver having fulfilled responsibilities in an official capacity, he treats lightly the difficulties which appertain even to the launching of such a scheme as lie has put before us to-day. He has quoted the instinces of France and Germany. I think those very instances will give to this audience at once a practical illustration of the difficulties that lie in the way of any speedy realisation of a complete scheme such as Mr. Furley puts before us, for anyone who knows the circumstances of Germany and France knows that the whole nation in each case is armed to the teeth for a specific purpose-for the purpose of defence against its neighbour, who is only separated by an imaginary geographical line. Every individual, every centre geographical or strategical, is organised in connection with the general scheme of defence for the country under the military authorities. Therefore, the first point I would put before Mr. Furley for consideration to-day is, that while he may go on instructing public opinion so as to bring pressure upon the authorities to take action, it is to the authorities that we must look for taking the practical initiative in working out any such schemeas that which he has brought forward. In the first place, it is perfectly impossible, I subnit with all deference, for a civilian gua civilian upon his own initiative to map out districts, to allocate hospitals and their equipment. But this is still more the case, I submit, when you come to the personncl, and have to organise those according to their duties, for when you come to this matter of duties you come to the line which is the most difficult to apportion between the active army and those who are in the civil population. But while this is so, I do not want to enhance too much the difficulties, because I believe there is a spirit abroad, which I referred to before, that it is necessary to put our means of defence into something like organisation. There is one little point, to illustrate what I have been saying as to instructing public opinion, on which, I think, we should make a departure at once, that is, by instructing people as to what the Geneva Cross really means. Now, the authorities, I think, themselves are the greatest offenders in connection with this matter. They have permitted the use of the Red Cross upon our Army Hospital Corps as if it were a sign which they ought to wear officially. I demur to that entirely. I say it is most mis-

VOL. XL. 
leading. The Geneva Cross ought never to be worn except in the ficld of active war operations: Therefore, I say, the very first thing to be done is to bring home to the military authorities a better understanding of the Geneva Convention, and get them to take at once the step of abolishing the use of the Red Cross on the uniform of the Army Hospital Corps. Again, with regard to the civilian population, this may also have its application. I think $I$ have seen, if my eyesight has not deceived me, Volunteers marching through the metropolis with the Red Cross on their arms and in their hands a rifle. The two things are absolutely in contradiction to one another. The Red Cross is to give you such inmunity as may be possible from those dangers which attend the actual use of fire-arms by combatants as a weapon of offence or defence. Then I think we might go further, and Sir Alfred Jephson gave me the thought as he,was speaking, in regard to the use of the Red Cross in connection with advertisements. We know what has been done with regard to naval and military uniforms. It is not so very long ago that it was a perfect disgrace to see sandwich men using Her Majesty's uniform in carrying advertisements of something perhaps more or less questionable. I see no difficulty in the slightest degree in the Government of the day, understanding what the Geneva Convention is, and that the Red Cross is the practical sign of the privileges which are conveyed by that Convention, passing a short Act of Parliament making it prohibitory for tradesmen or anyone else to use the Red Cross. I thisk there is another difficulty in which I have found myself in regard to planning out such ideas as Mr. Furley has urged us to take. If there is one power in England which is more potent than another, it is philanthropy. I myself have had the honour to represent our British National Society for Aid to Sick and Wounded in War on various occasions abroad, and many and many a time, against my better judgment, I have been foreed by the irresistible wave of public philanthropy at home to conmit some of the indiscretions which Mr. Furley has pointed out. I have never had an opportunity of publicly confessing my sins before, but I am glad to take this opportunity to illustrate that there are some kinds of forces which we cannot disregard, and one of these is the philanthropy of England. In the expedition to Khartoum in 18S4-3, I even believe it overcame the opposition of the military authorities, who were by no means cnamoured of having to carry out some of the objects desired by public philanthropic opinion. These are just a few observations which, as a practical man, scemed to occur to me; but at the same time, I do wish to reiterate that the present time is most opportune for making any new departure in regard to providing for the necessities which Mr. Furley has pointed out, and I do hope that this discussion to-day, and the reading of the paper, may lead to some practical effort being made.

Surg.-Lieut. G. R. J. Fletcher, 22nd Middlesex (Central London Rangers), V.R. : Not being a ware this lecture was taking place this aftemoon, I arrived late, and not having been here at its conmencement have not heard all that Mr. Furlcy has said. As far as I could gather, Mr. Furley suggests that the St. John Ambulance Association shall take the place in war of those organisations that we ought to have in our Volunteer Army, Mr. Furley looks upon the use of this great society which he would form as an enlargement of the National Red Cross Society. The invasion of England is the situation considered by Mr. Furley, and the question I want to ask him is, Where in the scheme of home defence does he propose to utilise the St. John Ambulance Association? It seems to me that this association is not one which could be brought to the front, nor perhaps in these days will it be possible, except in certain positions where there is cover, to clear the field till after an action. If it is a question of their use in field hospitals, or hospitals which may be formed upon the lines of communication, the point is, whether it would not be better to utilise the large material we have in the nursing staffs of our general hospitals and associations of nurses. There is aiso the large number of medical students - what they are all going to do, goodness only knows - who might perhaps be able to do better work if they were organised than the St. John Ambulance. I would ask 
the lecturer what experience can members of the St. John Ambulance have of hospitals and the large knowledge and training necessary to miake an efficient nurse? Mr. Furley say's the number of wounded on the field of battle would be very largely increased. That is the opinion of some. Dr. Fischer, of Berliri, in at paper which he published last year on the removal of wounded during war puts on 30 per cent. These sensational estimates are giving way now to more sober ones. Thirty per cent. casualties Baker Pasha considered the breakirig straitt of the best troops, and such a percentage has only been reached on two occasionis: Surgeon-Captain Melville in the Journal of the United Institution of Indid, for December, thinks the number of wounded will be somewhat increased, and puts it at 10 per cent. The number of killed, however, will be probably increased from one to six, to: one to three, and if that is so it will rather lighten our labours than make then heavier. It seems to me that we want some definite lines to go upon. It is all very well to say we require more than we have. We all know that, but what we want to know is, How you are going to utilise these associations for the special purposes required? As far as I ean see it can only be done by training them specially in hospitals in time of peace, and that, I am afraid, for the ordinary civilian population is impossible. Besides this there is the question of organisation. With regard to some remarks that Colonel Young made as to Volunteers carrying a rifle and wearing the Geneva Cross, I think he will acknowledge that he has not seen that lately. The authorities recoguised some time ago that the fact that a regimental bearer wearing the Red Cross was an anomaly, and they abolished its use sinee the 1894 Regulations. It is the fault of the Colonel or perhaps the medical officers if any man is now seen wearing it ; unless, indeed, he belongs to a bearer company, and then he has no right to carry the rifle. With regard to the question of the Red Cross worn by the Medical Staff Corps (called the Army Hospital Corps by several this afternoon, though that litle has becn dead for ten years); as this corp's is utilised solely for carrying and nursing the wounded, there can hardly be any objection to its membors wearing this badge. In the case of war against barbarians, they have to carry rifles for their own protection; and as the Geneva Cross is not understood or recognised by the enemy, there can be no objection to its use. Undoubtedly, there is a great abuse of the Geneva Cross as a badge in England, and if this meeting does something towards abolishing its misuse on advertisements and a few other things, it will have done a considerable amount of good. Major Maclure, an old friend of mine, has rather patted us on the back with the Volunteer Ambulance Department. I do not know that department, though I know the Volunteer Ambulance School of Instruction, of which Major Maclure is Prèsident; it is a school which has done a great deal of good work, but I am sure Major Maclure will pardon me if I suggest that it has no right to speak for the whole of the Volunteer force. What I would ask Mr. Furley is, on what lines he proposes to utilise this great St. John Ambulance Association for the welfare of the wounded in case of invasion?

Mrs. Bedford Fexwick : Lord Knutsford, ladies, and gentlemen,-Women have not been requested to speak in this discussion; therefore, perhaps I ought to apologise for saying a few words on the subject. But, as a trained nurse, I should like to make a few remarks with regard to the organisation of a Volunteer corps of nurses. In 1859, I drew up a scheme and submitted it to the head of the medical department of thie War Office, but as I have heard nothing since from the department, it, like other important documents which have been mentioned, I presume. has been pigeon-holed. Some two years ago the question of the formation of a Volunteer corps of nurses was again raised; in connection with the Royal British Nurses' Association, and I believe that Her Royal Highness 'rincess Christian is now occupied in considering the practical details of such a scheme. I do not think it has yet been orgatnised, but there is every reason to hope that in due time it will be carried out successfully. The suggestion made by the last speaker that it was impossible that really efficient nursing can be done by persons who are 
untrained, I think, is beyond dispute. What we want with regard to the formation of a corps of nurses is that the authorities should be able at a moment's notice in time of war to put their hands upon a number of the most efficient nurses, thoroughly trained women; and, of course, these women would have to be under military discipline. But I quite believe with the help of these other bodies which have been mentioned by Mr. Furley some arrangement could be made by means of which a Volunteer corps of nurses could be thoroughly equipped and kept in readiness, so that at twenty-four hours' notice we should ba able to supply the place of our trained sisters and nurses in the hospitals at home or abroad, or, if necessary, to send them on active service. I do not think any other system would be really efficient. It is not only useless, but it would be wrong, because it would be fraught with dangerous results, to place the nursing of the sick in the hands of untrained nurses.

Dr. J. Edward Sqtire, M.D.: May I be allowed one word, to bring the speakers back to what appears to me to be the keynole of Mr. IFurley's paper, i,e., organisation? $M y$ reason for speaking is, that in the few remarks we have heard, we have had on crery side a representative of some particular body, and seeing that all these different spenkers have represented some separate and distinct body, we see the very need that Mr. Furley has spoten of for organisation. We have the British Red Cross Society, which remains in abeyance, except when a campaign brings it into temporary vitality again. We have the St. John Anbulance Association always with us; we have the British Nurses' Institution; we lavie the Volunteer Medical Staff Corps; the Volunteer Ambulance Depart. ment; the Volunteer Regimental Stretcher Bearers. We have associations of all kinds, all of them capable of doing good work, and all unable to do what they would willingly undertake, for want of organisation. And so I think the main thing we have to consider, is, How can we organise these various bodies, so that each may be available in case of emergency? To my mind, the British Red Cross Society is the body to do the organisation; the other associations to which reference has been made are the bodies to do the training.

Dr. BezLY THoRNe, M.D. : I feel perfectly confident that if the hint thrown out by Mr. Furley and others were attended to, and the authorities would givean idea of the lines on which the desired organisation should be carried out, there would be no difficulty whatever in completing in the course of a very few months the organisation required for the nursing of any great -central hospital or base hospitals which the military authorities might think necessary to have fumished in time of war or invasion. The whole question is waiting for the encourngement and direction of the authorities, and if that once be given I feel confident that the whole question can be settled very quickly as regards the provision of a proper nursing staff, which, as has already been said, should consist entirely and wholly of those who have had a thorough hospital training.

Mr. FlRLeY : I need not detain you very long in reply. I am very glad there has been some little discussion. With regard to the remarks of my friend Colonel Young, he seems rather surprised at the very large scheme I placed before the meeting. I think we need not discuss the matter any further here, as he and I in the course of conversation will be able to settle that question, and I feel sure I can show him that it is not such a very large undertaking as he imagines. With regard to the remarks of Surgeon-Lieutenant Fleteher, I am only sorry that he did not hear the commencement of the paper, because he would have then been satisfied that I did not come here with any intention of putting the St. John Ambulance Association forward in too prominent a position. He would have heard that I mentioned other important associations, and put them all on an equality of usefulness; and I think there would not be the slightest difficulty in organising such a scheme as I have ventured to propose, especially when we have before us the organisation now existing in France, of which I have given rather a long 
account. Of course, as a very old member of the St. John Ambulance Association I should be very glad if work in this direction could be found for that institution, but I certainly would not leave out one of those useful bodies to which I have referred. I do not think there is anything further that requires an answer.

The Cuniryas (Lord Knutsford): I understand it is the practice here in asking you to return a vote of thanks to Mr. Furley for his most excellent and able address, to close, as it were, the discussion by saying a few words. Certainly upon this occasion very few words are necessary, for I think it cannot be doubted that there is a very substantial adhesion on the part of all present to the views that have been stated by Mr. Furley. One gentleman, no doubt, thought that Mr. Furley went too far, but it is always safe to have a margin upon which you can retire and which you can concede to the other side. I have no doubt Mr. Furley and Colonel Young together would very snon arrange matters. It appears to me that $\mathrm{Mr}$. Furley had two objects in view indelivering this address. The first was a very important one, viz., to recall to our ninds the principle of the Convention of Geneva of 1864 . It is quite clear from his address that the principle has been lost sight of, perhaps because fortunately we have not since that date been engaged in war with belligerent Powers who have become parties to that Convention. But it is well worth remembering that the working of the Convention of Geneva, that is to say, the protection and the neutral position which are given under it to those who are relieving the sick and wounded in war, that working only commences when war is declared between belligerents who have become parties, either in 1864 or subsequently, to the Convention of Geneva, and that with the cessation of war all active operation of the Convention of Geneva ceases. That seems to have been forgotten, and what also seems to have been forgotten is that there are certain conditions attached by the Convention of Geneva to those who desire to obtain protection and neutrality under it. Those conditions have been pointed out by Mr. Furley, and they must be observed. There are many persons who seem to have thought that because they were members of Red Cross Societies or Aid Societies or Ambulance Orders, and indeed many people who were not members of any such society have seemed to think, that they could have the protection which is secured by the Convention of Geneva to those who give assistance to the rounded in time of war if they merely tied an armlet round their arms. They supposed that by doing this they were satisfying alr that was required by the Convention of Geneva. The sooner that delusion is disposed of the better it will be for all concerned. It cannot be too strongly urged, as Mr. Furley mentioned at the beginning of his address, that "the Red Cross is a military and not a civil badge, and that no person is authorised to use it without official authority." That is, I think, the first object of his address, to recall to our minds the operation of the Convention of Gencrat. And the second object of his address is what has been urged by many others present to-day, the immense importance of organising in times of peace societies which train up men and women to hospital and ambulance work; and in passing I may observe that I most entirely concur in what has been said by Mr. Furley as to the importance of having women who have been trained to hospital work. The point Mr. Furley urges is that we should in times of peace organise those societies so as to have trained men and women ready to act when war breaks out. There is an old saying that a poet is born and cannot be made : the exact converse applies to our adept in the relief of the wounded. Certainly no man or woman has been born an adept, and it requires a continuous careful and close training to make a skilled adept in giving such relief. It is to these societies that we must look for the providing of trained men and women ready to take up their duty in time of war. It seems admitted by the foreign authorities to whom Mr. Furley has referred, that the medical corps of a great army-however able and adnirable they may be, and no one for a moment could doubt the ability and good work and energy of the medical corps of our 
Army-must have a Voluntecr Reserve in time of emergency. I think it was only two or three years ago that Lord Wolseley, the present Conmander-in-Chicf, in addressing an ambulance brigade he had inspected at Nottingham, fully adnitted this, and he spoke of the work done by those societies as of the greatest use and likely to prove of the greatest advantage in time of war, supposing there was any invasion of this country. It is therefore important that we should, if we possibly can, after hearing this lecture arrive at some plan of organising and getting the co-operation of these societies, so that if unfortunately war should break out we should have a good Volunteer Reserve of trained men and women to assist in time of war. With these very few words I will conclude by asking you to unanimously give a vote of thanks to Mr. Furley for his excellent address. 